\title{
Academic Cheating and Characteristics of Accounting Students
}

\author{
Nur Sayidah ${ }^{1}$, Sulis Janu Hartati ${ }^{2} \&$ Muhajir $^{2}$ \\ ${ }^{1}$ Faculty of Economics and Business, Dr. Soetomo University, Surabaya, Indonesia \\ ${ }^{2}$ Faculty of Education, Dr. Soetomo University, Surabaya, Indonesia \\ Correspondence: Nur Sayidah, Faculty of Economics and Business, Dr. Soetomo University, Surabaya, Indonesia.
}

Received: September 16, 2019

doi:10.5430/ijfr.v11n1p189
Accepted: October 27, 2019 Online Published: November 3, 2019

URL: https://doi.org/10.5430/ijfr.v11n1p189

\begin{abstract}
This paper aims to examine the correlation between perceptions of incentives, pressures, and rationalizations in academic cheating with student characteristics. Researchers used the survey method by distributing questionnaires to accounting students in various public and private universities in Indonesia. The results of Pearson Correlation Bivariate analysis of 386 respondents' answers show that there was a significant negative relationship between student academic performance and length of study with the desire and rationalization of students to conduct academic cheating. There is a significant negative correlation between the length of worship and the rationalization of students to be dishonest. Results indicate further research can use regression analysis to examine the effect between the variables studied. Implications of this study are lecturers need to internalize the value of honesty in the learning process. College management needs to develop policies that give strict sanctions to students who cheat.
\end{abstract}

Keywords: academic cheating, incentive, opportunity, rationalization

\section{Introduction}

Fraud is a serious problem that occurs both in the business and academic world. In the world of business, employees, management, and consumers can make fraud. The result of Sayidah research (2016) at the regional health insurance shows that doctors, patients, and hospitals had committed fraud. While in the academic field, the results of Simkin and Mc. Leod (2010) at Duke University shows that 60\% of business students and $64 \%$ of non-business students admit to being dishonest. Student academic dishonesty can be in the form of cheating during exams, asking for third-party assistance during exams, conducting electronic cheating / E-cheating (Eastman e.al, 2008).

Research on academic fraud has been carried out in various countries. A survey conducted at four tertiary institutions located in Queensland of 1,206 students and 190 academic staff showed tolerance of academic violations committed by students (Brimble and Clarke, 2005). A survey of students from various campuses in America conducted by McCabe (1997) shows that individual and contextual factors had influenced student dishonesty. The results of research using a full-factorial within-subjects ANCOVA design of 182 students in accounting, finance, information systems, management, and marketing courses at a major state university in California show that the pressure, opportunity, and rationalization significantly increase student trends to commit fraud (Choo \& Tan, 2015). A survey of 421 students from various classes with different majors at two state universities in the southern United States shows that students who have strong reasons for conducting unethical academic behavior are more likely to commit academic dishonesty than those who have weaker reasons for Unethical academic behavior (Eastman et al., 2018). Research conducted on 476 business students at Midwestern University shows that the age and frequency of students attending parties influence fraudulent behavior (Becker et al., 2006). In Islamabad, research that sampled 300 undergraduate students from five different institutions namely NUST Business School (NBS), Bahria University, FAST, Islamic International University (IIU) and Shifa Medical College showed that there was an influence of parental pressure, difficulty level of exam questions and lack of preparation for cheating by students (Batool et al., 2011).

The diversity of factors that influence academic dishonesty behavior shows that research in this area is still open. The researcher was motivated to conduct this study to test the correlation between the students' perception variables on incentives, pressure, and rationalization in conducting academic cheating with the academic achievement index variables, length of study, length of work on the assignment, length of worship, frequency of expression and gender. The results of this study can provide several contributions. First, add literature related to factors affecting dishonesty behavior undertaken by students. Second, provide a better understanding of lecturers about the seriousness of the problem of student dishonesty so that they can find solutions to solve it. Third, 
become input for the management of higher education to make regulations on sanctions to students for dishonest behavior.

\section{Literatur Review}

\subsection{Fraud Triangle}

Fraud Triangle was first introduced by Donald R. Cressey, who said that three things that encourage fraud behavior, namely pressure, opportunity, and rationalization (Machado and Gartner, 2018). The following picture is the fraud triangle:

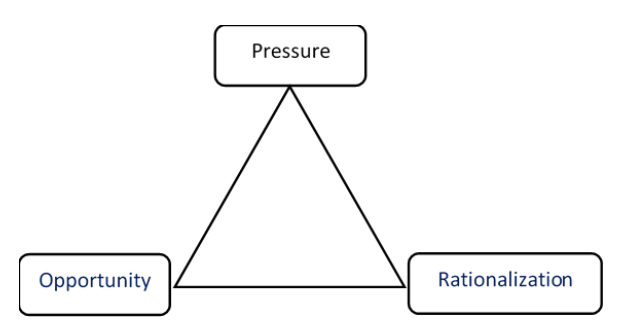

Figure 1. Cressey's fraud triangle

Source: Machado dan Gartner (2018)

Pressure, also known as incentive or motivation, refers to something that happens in the personal life of a fraudster (a fraudster) that creates a need that motivates a fraudster to commit fraud (Singleton \& Singleton, 2010; Wolfe and Hermanson, 2004). Conditions related to immorality, emergencies, increased needs, reversals in the business environment and a high standard of living standards are the main factors for fraud (Machado and Gartner, 2018; Schuchter and Levi, 2013). The greater the incentive or pressure, the more likely a person will be able to rationalize fraud (AICPA, 2002).

Opportunity becomes the second aspect that drives fraud. Fraudsters have the knowledge and opportunity to commit fraud and obtain sufficient knowledge about how to commit the crime (Singleton \& Singleton, 2010). The results of interviews with four male accountants who have been proven to commit fraud show that they commit fraud by utilizing their position as professional accountants (Dellaportas, 2013). The absence of controls or ineffective controls also provides an opportunity for fraud to be committed (AICPA, 2002). People who can take advantage of system weaknesses so fraud can occur (Wolfe and Hermanson, 2004).

People will commit crimes because they have certain needs as their motives. They have conditions that allow for fraud and rationalization of their actions (Cendrowski et al., 2007). Free (2015) classifies rationalization types into ten categories, namely moral justification, advantageous comparison, euphemistic labeling, ignore consequences, denial of the victim, displacing responsibility, diffusing responsibility, entitlement, disbelief, temporary loan. Rationalization has convinced actors that this fraudulent behavior is worth the risk (Wolfe and Hermanson, 2004). They convince themselves that committing an offense is an act that can be justified and accepted (Machado and Gartner, 2018). The greater the incentive or pressure, the more likely a person will be able to rationalize fraud (AICPA, 2002).

\subsection{Academic Fraud and Factors Influencing}

Cizek $(2003,42)$ has grouped fraudulent behavior in the academic field, known as the Cizek taxonomy into three categories, namely 1) giving or receiving information from others, 2) using materials that are not permitted by lecturers to complete assignments, and 3) take advantage of weaknesses to get benefits, for example when supervisors come out of the examination room. Previous researchers had done some research on factors that affect student academic performance. Batool et al., 2011 found parental pressure, lack of preparation in taking exams, the amount of time spent on extra-curricular activities, and the academic achievement index influenced student cheating behavior (Batool et al., 2011). The age and frequency of students going to parties also significantly influence academic cheating (Becker et al., 2006).

Students who commit academic cheating because they feel the assessment indicators are too much and require a lot of time to do, collected at the same time with other assignments, intended to help friends, unclear academic error criteria related to plagiarism and the belief that the lecturer will not discover their cheating (Brimble and Clarke, 2005). The survey results of Iberahima et al. (2013) in Malaysia showed three main reasons students cheated, namely tolerance from lecturers, the irrelevance of materials or assignments, and pressure from classmates. Another reason is feeling will not harm anyone, will not be caught, challenges, everyone does it, does not have enough time to study and do assignments, hard time) but do not prepare adequately, the task is 
difficult and to obtain high grades.

Student grade level (SAP) has the potential to influence student cheating. Students who have better grades have less desire to cheat or have less rationalization for dishonest (Becker, et al., 2006). Lecturers can reduce the opportunity for students to cheat by making rules both at the beginning of the semester, during exams, and when working on assignments (Hayes et al., 2006). At the beginning of the semester, the lecturer can include rules in the student contract

\section{Method}

\subsection{Data}

This study uses a survey method by distributing questionnaires to accounting students in public and private universities in Indonesia. Researchers contacted several accounting lecturers at various universities to ask for help in distributing questionnaires. Questionnaires were designed online using google form with the site https://forms.gle/bvimyhz75oqQrSgs6. Students only need to visit the site and complete the questionnaire online. Researchers managed to collect 386 questionnaires. Respondents who had filled in the questionnaire form came from 17 universities, namely: (1) University of dr. Soetomo (2) Prasetiya Mulya University (3) UPN Veteran East Java (4) UPN Veteran Yogyakarta (5) STIE Malangkuceswara (6) Brawijaya University (7) Tadulako University (8) Surabaya University (9) Indonesian College of Economics (10) ) Rawamangun College of Economics (11) Wijaya Kusuma University (12) Airlangga University (13) Gadjah Mada University (14) Ganesha Education University (15) Gorontalo State University (16) Widya Mandala Catholic University Surabaya (17) Malang State University.

\subsection{Variable}

The researcher uses the fraud triangle variable, which includes incentive, opportunity, and rationalization. The researcher measure this variable by a questionnaire indicator adopted from Becker et al. (2006) using a scale of 4 , namely (1) Strongly Agree to (4) Strongly Disagree.

$\checkmark \quad$ Incentive, indicating the level of desire (encouragement) of students to commit dishonesty. Questionnaire questions include (1) the class is too difficult or too much work, (2) students feel they can't get the grades they want without cheating, (3) the exams are too difficult, and students don't have enough time due to outside commitments.

$\checkmark$ Opportunity, shows the level of discretion of students to commit dishonesty due to weak supervision and sanctions of lecturers. The opportunity indicators include (1) the instructor does not check for plagiarism, (2) the instructor does not change homework assignments or exams between terms, (3) the instructor observe other students cheating, and the instructor does not adequately deter cheating.

$\checkmark$ Rationalization is the perception of students to justify their academic dishonesty behavior. Indicators of rationalization include (1) the instructor's grading policies or workload requirements are unfair, (2) the instructor did not adequately explain what constitutes cheating, or the penalties for being caught cheating, and (3) faculty do not usually detect cheating.

Other variables used are:

$\checkmark \quad$ Variable of Student Performance Academic (SAP) is the academic achievement of students ranging from 0 to 4. SAP is divided into five categories, namely (1) $0-2.00$ (2) $2.01-2.50$ (3) $2,51-3.00$ (4) 3.01 - 3.50 (5) 3.51-4.00.

$\checkmark \quad$ Variable of the amount of time spent studying (Study), doing assignments (Assign), and praying per week (Pray). The researchers categorize into three scales, namely (1) 0-5 hours (2) 6-10 hours (3)> 10 hours.

$\checkmark \quad$ Variable frequency of doing entertainment activities, namely Recreation per week, is categorized into three, namely (1) 0-1 times (2) 2-3 times (3)> times.

\subsection{Analysis Model}

The analytical model used in this study is the Pearson Correlation Bivariate.

\section{Results}

\subsection{Descriptive Statistics}

Respondents who filled out the questionnaire in this study were 386 people; almost all of them were undergraduate level. Respondents who study in the master's program are three people, and there are five doctoral levels. Based on gender, 279 people, or $72.3 \%$ are female students, and 107 people, or $27.7 \%$ are male students. This data can illustrate that the majority of accounting students in Indonesia are women. The following table explains the full descriptions of the questionnaire answers. 
Table 1. Descriptive statistics

\begin{tabular}{llllll}
\hline & $\mathrm{N}$ & Minimum & Maximum & Mean & Std. Deviation \\
\hline SAP & 386 & 2.00 & 5.00 & 4.4119 & .65960 \\
\hline Study & 386 & 1.00 & 3.00 & 1.9482 & .77788 \\
\hline Assign & 386 & 1.00 & 3.00 & 1.8990 & .71543 \\
\hline Pray & 386 & 1.00 & 3.00 & 2.1554 & .82600 \\
\hline Recreation & 386 & 1.00 & 3.00 & 1.7358 & .68575 \\
\hline Gender & 386 & 1.00 & 2.00 & 1.2772 & .44820 \\
\hline Incentive & 386 & 1.00 & 4.00 & 2.3696 & .56331 \\
\hline Opportunity & 386 & 1.00 & 4.00 & 2.4352 & .58207 \\
\hline Rationalization & 386 & 1.75 & 3.75 & 2.5926 & .34189 \\
\hline Valid N (listwise) & 386 & & & & \\
\hline
\end{tabular}

Source: SPSS Output, (2019).

The table above shows that the variable Student Academic Performance (SAP) has a number that varies from 2.00 to 5.00. Students in this study had the lowest SAP in category 2, which ranged between 2.01-2.50 and the highest in category 5, which ranged from 3.51-4.00. There are no respondents who have SAP below 2.00. If seen from the average data, Most of these variable values are close to the maximum number Other independent variables, namely the amount of time spent studying (Study), doing assignments (Assign) and pray per week (Pray) and the frequency of doing recreational activities (Recreation) in one week have the same minimum and maximum numbers. The average Study, Assign, Pray, and Recreation variables are close to category 2. Students spend an average of 6-10 hours per week to study, do assignments, and pray.

Furthermore, students enjoy recreation, on average, 2-3 times per week. Other variables consisting of Incentive, Opportunity, and Rationalization to commit academic dishonesty have an average of close to 2.5 . The average of students does not agree with cheating behavior to get high grades.

\subsection{Test of Validity and Reliability}

Test of validity and reliability were carried out on questionnaires for the dependent variables, namely Incentive, Opportunity, and Rationalization. The researcher used the validity test with Pearson Correlation and reliability test with Cronbach's alpha.

\subsubsection{Result of Validity Test}

The test results of validity are as follows:

Table 2. Validity statistics of incentive variable

\begin{tabular}{lllll}
\hline & Incentive1 & Incentive2 & Incentive3 & IncentiveT \\
\hline Incentive1 & 1 & & & \\
\hline Incentive2 & $.652^{*}$ & 1 & & \\
\hline Incentive3 & $.311^{*}$ & $.266^{*}$ & 1 & \\
\hline IncentiveT & $.873^{*}$ & $.827^{*}$ & $.631^{*}$ & 1 \\
\hline
\end{tabular}

*Correlation is significant at the 0.01 level (2-tailed).

Source: SPSS Output, (2019).

The correlation of Incentive items 1 to Incentive items3 to total IncentiveT varies between 0.631 to 0.873 with a significant (2-tailed) level of 0,000. Based on these results, the Incentive variable is declared valid.

Table 3. Validity statistics of opportunity variable

\begin{tabular}{lllll}
\hline & Opportunity 1 & Opportunity2 & Opportunity3 & OpportunityT \\
\hline Opportunity1 & 1 & & & \\
\hline Opportunity2 & $.574^{*}$ & 1 & & \\
\hline Opportunity3 & $.439^{*}$ & $.581^{*}$ & 1 & 1 \\
\hline OpportunityT & $.809^{*}$ & $.866^{*}$ & $.813^{*}$ & \\
\hline
\end{tabular}

*Correlation is significant at the 0.01 level (2-tailed).

Source: SPSS Output, (2019). 
The correlation of Opportunity items 1 to Opportunity items 3 to the total Opportunity T varies between 0.809 and 0.866 with a significant (2-tailed) level of 0,000 . Based on these results, the Opportunity variable is declared valid.

Table 4. Validity statistics of rationalization variable

\begin{tabular}{llllll}
\hline & Rat.1 & Rat.2 & Rat.3 & Rat.4 & Rat.T \\
\hline Rat.1 & 1 & & & & \\
\hline Rat.2 & $.091^{*}$ & 1 & & & \\
\hline Rat.3 & $.057^{*}$ & $.139^{*}$ & 1 & & \\
\hline Rat.4 & $.023^{*}$ & $.085^{*}$ & $.631^{*}$ & 1 & \\
\hline Rat.T & $.541^{*}$ & $.605^{*}$ & $.423^{*}$ & $.558^{*}$ & 1 \\
\hline
\end{tabular}

*Correlation is significant at the 0.01 level (2-tailed).

Source: SPSS Output, (2019).

The correlation of Rationalization items 1 to Rationalization items 4 to total Rationalization $\mathrm{T}$ varies between 0.423 and 0.631 with a significant (2-tailed) level of 0,000. Based on these results, the Opportunity variable is declared valid.

\subsubsection{Result of Reliability Test}

The test result of reliability is as follows:

Table 5. Reliability statistics

\begin{tabular}{ll}
\hline Cronbach's Alpha & N of Items \\
\hline .682 & 3
\end{tabular}

Source: SPSS Output, (2019).

The reliability test results showed the value of Cronbach's Alpha was 0.686, greater than 0.6. Based on these figures, the researcher stated that the questionnaire items in this study were valid

\subsection{Result of Pearson Correlation Analysis}

The results of data collection were analyzed using Pearson Correlation for all respondents' answers. Table 5 below shows the analysis results:

Tabel 6. Pearson correlation

\begin{tabular}{llll}
\hline & Incentive & Opportunity & Rationalization \\
\hline SAP & $-.276^{* *}$ & -.042 & $-.167^{* *}$ \\
\hline Sig. (2-tailed) & .000 & .411 & .001 \\
\hline Study & $-.136^{* *}$ & -.029 & $-.109^{*}$ \\
\hline Sig. (2-tailed) & .007 & .577 & .032 \\
\hline Assign & -.092 & -.040 & -.070 \\
\hline Sig. (2-tailed) & .071 & .437 & .167 \\
\hline Pray & $-.103^{*}$ & .071 & .016 \\
\hline Sig. (2-tailed) & .042 & .161 & .760 \\
\hline Recreation & .047 & .020 & .052 \\
\hline Sig. (2-tailed) & .354 & .696 & .308 \\
\hline
\end{tabular}

** Correlation is significant at the 0.01 level (2-tailed).

* Correlation is significant at the 0.05 level (2-tailed).

Based on the table above, we explained that there are three significant correlations between Incentive variables and other variables. First, the correlation between SAP and Incentive variables is -0,276 at a significance level of 0.00. Second, the correlation between Study variables and Incentives was $-0,103$ at a significance level of 0.00 . Third, the correlation between Pray and Incentive variables is -0.136 at the 0.047 significance level. These three correlation coefficients have significantly less than 0.05 and are negative. Students who have higher SAP, longer 
study hours, and longer worship times, have a lower level of desire to commit academic cheating.

Furthermore, there are two significant correlations between Rationalization variables and other variables. First, the correlation between SAP and Rationalization variables is -0.167 at the significance level of 0.00 . Secondly, the correlation between Study and Rationalization variables is -0.109 at the 0.03 significance level. Both of these correlation coefficients have a significance level of less than 0.05 and are negative. Students who have higher SAP and longer study hours have a lower level of rationalization for academic cheating.

Variable Opportunity has a small and not significant correlation with SAP, Study, Assign, Pray, and Recreation variables. Opportunity for academic dishonesty is not related to the level of SAP, the length of time spent studying and worshiping. The length of time spent doing work and the frequency of students enjoying recreation does not correlate with all of the fraud triangle variables, namely Incentive, Opportunity, and Rationalization. Students have provided a special time to do assignments and enjoy a vacation so that the activity does not interfere with academic interests.

\section{Discussion}

This paper has analyzed the student's fraudulent behavior in the academic field and its relationship with several variables that indicate student characteristics. Researchers have used the fraud triangle model to assess the desires, opportunities, and nationalization of students in committing academic cheating. Characteristics of students studied included SAP, length of study, work on assignments and worship, and frequency of recreational activities in one week.

The results of an analysis of 386 respondents from 17 state and private universities in Indonesia showed that the SAP and Study variables had a negative correlation with incentives and rationalization. Variable Pray has a negative correlation with Incentive. Students who have high SAP (clever) have a low desire to do dishonest. They realize that the act is unethical. They do not condone cheating behavior in the academic field. Students who have high SAP are honest students. They spend more time studying, so they always feel ready to face exams. This student has a lower tendency to cheat compared to students who are lazy to learn and worship. Students who have a high level of religiosity realize that cheating is a sin, and they must avoid. Dishonesty is not justified in any religion.

Lecturers can reduce academic dishonesty in certain ways. For example, lecturers develop learning methods that internalize values in students so that they become moral people (Sayidah et al., 2018a). A mental revolution becomes important to be included in accounting learning to produce ethical accountants (Sayidah et al., 2018b). Another way is for lecturers to give ethics training in the classroom to reduce or even eliminate student rationalization before they commit fraud. Lecturers can also reduce the opportunities for academic cheating by using mechanisms to prevent and detect fraudulent behavior. Therefore lecturers must know various cheating behavior techniques that are usually carried out by students (Hayes et al., 2006). In addition to lecturers, organizations need to strive to enhance ethical culture to reduce people's intention to commit fraud (Brown et al., 2016).

\section{Conclusion}

This paper has analyzed the student's fraudulent behavior in the academic field and its relationship with several variables that indicate student characteristics. Researchers have used the fraud triangle model to assess the desires, opportunities, and nationalization of students in committing academic cheating. Characteristics of students studied included SAP, length of study, work on assignments and worship, and frequency of recreational activities in one week.

The results of an analysis of 386 respondents from 17 state and private universities in Indonesia showed that the SAP and Study variables had a negative correlation with incentives and rationalization. Variable Pray has a negative correlation with Incentive. Students who have high SAP (clever) have a low desire to do dishonest. They realize that the act is unethical. They do not condone cheating behavior in the academic field. Students who have high SAP are honest students. They spend more time studying, so they always feel ready to face exams. This student has a lower tendency to cheat compared to students who are lazy to learn and worship. Students who have a high level of religiosity realize that cheating is a sin, and they must avoid. Dishonesty is not justified in any religion.

Lecturers can reduce academic dishonesty in certain ways. For example, lecturers develop learning methods that internalize values in students so that they become moral people (Sayidah et al., 2018a). A mental revolution becomes important to be included in accounting learning to produce ethical accountants (Sayidah et al., 2018b). Another way is for lecturers to give ethics training in the classroom to reduce or even eliminate student rationalization before they commit fraud. Lecturers can also reduce the opportunities for academic cheating by using mechanisms to prevent and detect fraudulent behavior. Therefore lecturers must know various cheating behavior techniques that are usually carried out by students (Hayes et al., 2006). In addition to lecturers, 
organizations need to strive to enhance ethical culture to reduce people's intention to commit fraud (Brown et al., 2016).

\section{Limitation and Further Research}

Evidence that there is a relationship between achievement, level of craft in learning and worship gives the implication that lecturers must provide a better understanding of academic integrity, especially for students who have low grades. Institutions need to develop policies to impose sanctions if students commit academic fraud. University management must make it clear that lecturers must apply policies strictly to students who act unethically. An assessment policy also needs to include cheating sanctions to minimize opportunities for cheating. All academicians need to prevent academic fraud by building a strong culture of academic honesty on campus. A lecturer can internalize the value of honesty to students.

This study is limited to correlation analysis so that it has not been able to measure the impact of an increase in student academic performance, the length of study, and worship on the decline in academic cheating. Future studies can use regression analysis to examine the effect of the variables studied. Besides, the site of this research is in Indonesia. The further researcher can study by expanding respondents in various countries so that researchers can compare between countries.

\section{Acknowledgment}

This paper is the result of research funded by the 2019 research grant. We thank the Directorate of Research and Community Service, the Directorate General of Research Strengthening and Development, the Indonesian Ministry of Research, Technology, and Higher Education.

\section{References}

AICPA. (2002). AU Section 316 Consideration of Fraud in a Financial Statement Audit (Supersedes SAS No. 82). Effective for audits of financial statements for periods beginning on or after December 15, 2002, unless otherwise indicated. Retrieved from https://www.aicpa.org/Research/Standards/.../AU-00316.pdf

Armstronga, M., B., Ketzb, J. E., \& Owsen, D. (2003). Ethics Education in Accounting: Moving Toward Ethical Motivation and Ethical Behavior. Journal of Accounting Education, 21, 1-16. https://doi.org/10.1016/S0748-5751(02)00017-9

Association of Certified Fraud Examiners Indonesia Chapter. (2017). Survey Fraud Indonesia, pp.1-66.

Batool, S., Abbas, A., \& Naeemi, Z. (2011). Cheating Behavior among Undergraduate Students. International Journal of Business and Social Science, 2(3), 246-254.

Brimble, M., \& Stevenson-Clarke, P. (2005). Perceptions of the prevalence and seriousness of academic dishonesty in Australian universities. Australian Educational Researcher, 32(3), 19-44. https://doi.org/10.1007/BF03216825

Brown, J. O., Hays, J., \& Stuebs, M. T. Jr. (2016). Modeling Accountant Whistleblowing Intentions: Applying the Theory of Planned Behavior and the Fraud Triangle. Accounting and the Public Interest, 16(1), 28-56. https://doi.org/10.2308/apin-51675

Buchholz, A. K. (2012). SAS 99 : Deconstructing the Fraud Triangle and Some Classroom Suggestions. Journal of Leadership, Accountability, and Ethics, 9(2), 109-119.

Cendrowski, H., Martin, J. P., \& Petro, L. W. (2007). The Handbook of Fraud Deterrence. John Wiley \& Sons, Inc.

Choo, F., \& Tan, K. (2015). The Effect of Fraud Triangle Factors on Students' Cheating Behaviors. Advances in Accounting Education: Teaching and Curriculum Innovations, 9, 205-220. https://doi.org/10.1016/S1085-4622(08)09009-3

Dellaportas, S. (2013). Conversations with inmate accountants: Motivation, opportunity, and the fraud triangle. Accounting Forum, 37(1), 29-39. https://doi.org/10.1016/j.accfor.2012.09.003

Eastman, J. K., Iyer, R., \& Reisenwitz, T. H. (2008). The Impact of Unethical Reasoning on Different Types of Academic Dishonesty: An Exploratory Study. Journal of College Teaching \& Learning, 5(12), 7-16. https://doi.org/10.19030/tlc.v5i12.1211

Free, C. (2015). Looking through the fraud triangle: a review and call for new directions. https://doi.org/10.1108/MEDAR-02-2015-0009

Hayes, D., Hurtt, K., \& Bee, S. (2006). The War on Fraud: Reducing Cheating in the Classroom. Journal of College Teaching \& Learning, 3(2), 1-12. https://doi.org/10.19030/tlc.v3i2.1742

Iberahima, H., Hussein, N., Samatc, N., Noordind F., \& Daude, N. (2013). Academic dishonesty: Why business 
students participate in these practices?. Procedia - Social and Behavioral Sciences, 90, 152-156. https://doi.org/10.1016/j.sbspro.2013.07.076

Machado, M. R. R., \& Gartner, I. R. (2018). The Cressey hypothesis (1953) and an investigation into the occurrence of corporate fraud: an empirical analysis conducted in Brazilian banking institutions. Revista Contabilidade \& Finanças, 29(76), 60-81. https://doi.org/10.1590/1808-057x201803270

Madan, B. (2013, June). An Empirical Investigation of the Relevant Skills of Forensic. European Journal of Accounting Auditing and Finance Research, 1, 11-52.

Mui, G., Mailley, J., \& Mui, G. (2015). A tale of two triangles: comparing the Frand Triangle with criminology's Crime Triangle. https://doi.org/10.1108/ARJ-10-2014-0092

Olson, J., Shurden, M., \& Caines, R. (2004). Academy of Educational Leadership Journal. Academy of Educational Leadership Journal, 5(2), 127.

Sayidah, N. (2016, September 26). Makna Governance di Sektor Publik. Prosiding, International Conference, University of Widya Mandala Surabaya.

Sayidah, N. (2018). Internalization of the Values of Mental Revolution in Forensic Accounting and Investigative Audit Learning Models. Asia Pacific Fraud Journal, 3(2), 297-305.

Sayidah, N., Hartati, S., Muhajir, J., \& Wijayanti, R. (2018). Exploration of the Meaning of Mental Revolution Values in Forensic Accounting Context. International Journal of Management Sciences and Business Research, 7(11), 85-95.

Schuchter, A., \& Levi, M. (2013). The Fraud Triangle revisited. Security Journal, 29(2), 107-121. https://doi.org/10.1057/sj.2013.1

Simkin, M. G., \& McLeod, A. (2010). Why do college students cheat?. Journal of Business Ethics, 94, 441-453. https://doi.org/10.1007/s10551-009-0275-x

Singleton, T. W., \& Singleton, A. J. (2010). Fraud Auditing and Forensic Accounting (4th ed.). John Wiley \& Sons, New Jersey. https://doi.org/10.1002/9781118269183

Wolfe, D. T., \& Hermanson, D. R. (2004). The Fraud Diamond: Considering the Four Elements of Fraud. CPA Journal, 74(12), 38-42. https://doi.org/10.1016/S1361-3723(04)00065-X 